\title{
Effects of double stress on antioxidant enzyme activity in Vigna radiata (L.) Wilczek
}

\author{
ZAMIN S. SIDDIQUI* \\ Department of Botany, University of Karachi, Karachi 75270, Pakistan
}

\begin{abstract}
The effects of double stress environment i.e. lead (heavy metal) and $\mathrm{NaCl}$ (saline) on the activity of antioxidant enzymes in Vigna radiata seedling were studied. The antioxidant activities of enzymes, i.e of superoxide dismutase, catalase, ascorbate peroxidase, guaiacol peroxidase, glutathione reductase and their activity proportions were examined. Superoxide dismutase, ascorbate peroxidase, guaiacol peroxidase and glutathione reductase activities were substantially increased in a combined stress environment as compared to catalase. Further, in comparison with catalase and ascorbate peroxidase, glutathione reductase showed increased activities together with superoxide dismutase in a combined stress environment. Superoxide dismutase and glutathione reductase showed higher activity proportion in combined treatment. Physiological role of these enzymes in stress tolerance mechanism is discussed.
\end{abstract}

KeyWord: Antioxidant, catalase, enzyme activity, glutathione reductase, guaiacol peroxidase, scorbate peroxidase, seedling, stress, superoxide dismutase, Vigna radiata

Abbreviations: APX - ascorbate peroxidase, CAT - catalase, GPX - guaiacol peroxidase, GR - glutathione reductase, ROS - reactive oxygen species, SOD - superoxide dismutase

\section{Introduction}

Environmental stress factors like drought, temperature, high salinity and heavy metals are the major constraint that limit plant growth and productivity, by disturbing the intracellular water balance. Usually, in fields or on agricultural land, unlike in a laboratory or even a greenhouse environment, plants are subjected to a manifold array of stress factor (SidDiQui et al. 2008, NAwAZ et al. 2010). However, most of the studies have been devoted to assess the physiological response of plants in a single stress environment like salinity (Sinha 1991, Sharma and Gills 1994, Kumar and Kumar 1996), drought (ShinOzaKi and YAMAGUCHI 2007) and heavy metals (HAMEED et al. 2000, JETLEY et al. 2004) and studies on the physiological responses of plants under a combination of such stresses are restricted to

* Corresponding address, e-mail: zaminss@uok.edu.pk

Copyright ${ }^{\circledR} 2013$ by Acta Botanica Croatica, the Faculty of Science, University of Zagreb. All rights reserved. 
just a few reports (WANG et al. 2003, DudLey and Shani 2003, WANG and HuAng 2004, JAKAB et al. 2005) and even they are not directly related to the combination of stress factors like heavy metal and salt stress.

Plants have utilized various mechanisms to combat with abiotic stresses. Among them, stress tolerance gene expression, compatible solutes, phenols and antioxidant enzyme production are some examples (JAKAB et al. 2005, Ahmed et al. 2010, SidDIQUi and KHAN 2011). Antioxidant enzymes such as superoxide dismutase (SOD) ascorbate peroxidase (APX), glutathione reductase, guaiacol peroxidase and catalase are well-known defense systems providing protection against the hazards of reactive oxygen species (ROS) in different stressful conditions (ALLEN et al. 1997, KwON et al. 2002, AHMED et al. 2010). Activities of these antioxidant enzymes are frequently observed in a single stress environment but the response and the proportion of the relative activities of these enzymes in a combined heavy metal (lead) and salt stress environment have seldom been reported. To make up for this lack, the present study examines the response of antioxidant enzymes and the proportions of their relative activities in a combined heavy metal (lead chloride and lead nitrate) and salt $(\mathrm{NaCl})$ stress environment. Lead is used in two forms to differentiate the effects of lead as chloride or nitrate together with sodium chloride environments.

\section{Material and methods}

Germplasm of Vigna radiata was obtained from the Pakistan Agriculture Research Centre Karachi University. Seeds were sterilized with 50\% Clorox for $10 \mathrm{~min}$, and then repeatedly washed with distilled water. The sterilized seeds were placed on moist Whatman 1 filter paper in Petri dishes and kept at $25{ }^{\circ} \mathrm{C}$ in the dark until germination. Germinating seeds were transferred into small plastic pots in a plastic tray (diameter $10 \mathrm{~cm}$, height $12.5 \mathrm{~cm}$ ) containing acid-washed sand. The whole set up waskept in a growth chamber with a 13-h photoperiod $\left(28{ }^{\circ} \mathrm{C}, 600 \pm 50 \mu \mathrm{mol} \mathrm{m}^{-2} \mathrm{~s}^{-1} \mathrm{PAR}\right)$ and $11 \mathrm{~h}$ night $\left(22^{\circ} \mathrm{C}\right)$ at $60-70 \%$ humidity. Plants were irrigated with $3 \mathrm{~L}$ of half-strength Hoagland's solution (HoAGLAND et ARNON 1950) until the plant developed five to six expanded leaves. Treatments were prepared in this order $\left(\mathrm{T} 1=15\right.$ and $30 \mathrm{mg} \mathrm{L}^{-1}$ lead chloride and lead nitrate, $\mathrm{T} 2=75,150$ and $225 \mathrm{mM} \mathrm{NaCl}, \mathrm{T} 3=15 \mathrm{mg} \mathrm{L}^{-1}$ and $3 \mathrm{mg} \mathrm{L}^{-1}$ lead chloride and nitrate in 75, 150 and $225 \mathrm{mM}$ $\mathrm{NaCl}, \mathrm{T} 4=$ half strength Hoagland solution (control). All the treatments were prepared in half strength Hoagland solution and poured separately in large size $(30.5 \mathrm{~cm})$ plastic plates in which pots were kept on alternate days. Plants were allowed to grow up to three weeks. Leaf samples of three weeks old plants were randomly collected from the treatments and the control and subjected to antioxidant enzyme activity estimation. All the treatments and controls were replicated four times.

\section{Extraction}

Randomly collected $500 \mathrm{mg}$ leaf samples were crushed in liquid nitrogen at $4{ }^{\circ} \mathrm{C}$ and homogenized in $10 \mathrm{~mL}$ protein extraction buffer containing Tris- $\mathrm{HCl} \mathrm{pH} 6.8,50 \mathrm{mg} \mathrm{PVP}, 10$ mL DDT, $0.1 \mathrm{mM}$ EDTA. The contents were centrifuged at 10,000 RPM for $15 \mathrm{~min}$. Total protein was estimated by the method of BRADFORD (1976) 
Catalase (Enzyme number by NC IUBMB: EC 1.11.1.6)

Catalase (CAT) activity was estimated by the method of PATTERSON et al. (1984). The decomposition of $\mathrm{H}_{2} \mathrm{O}_{2}$ was measured at $240 \mathrm{~nm}$ taking $\Delta \varepsilon$ at $240 \mathrm{~nm}$ as $43.6 \mathrm{mM} \mathrm{cm}^{-1}$. Reaction mixture $(3.0 \mathrm{~mL})$ consisted of $10.5 \mathrm{mM} \mathrm{H}_{2} \mathrm{O}_{2}$ in $0.05 \mathrm{M}$ potassium phosphate buffer $(\mathrm{pH} 7.0)$ and the reaction was initiated after the addition of $0.1 \mathrm{~mL}$ enzyme extract at $25^{\circ} \mathrm{C}$. The decrease in absorbance at $240 \mathrm{~nm}$ was used to calculate the activity. One unit of CAT activity is defined as the amount of enzyme that catalyzes the conversion of $1 \mathrm{mM} \mathrm{of} \mathrm{H}_{2} \mathrm{O}_{2}$ $\min ^{-1}$ at $25^{\circ} \mathrm{C}$.

Ascorbate Peroxidase (Enzyme number by NC IUBMB: EC 1.11.1.11)

Ascorbate Peroxidase (APX) activity was determined according to the method of NAKANO and ASADA (1981). The reaction mixture $(2.0 \mathrm{~mL})$ contained $0.05 \mathrm{M}$ potassium phosphate buffer (pH 7.0), $0.2 \mathrm{mM}$ EDTA, $0.5 \mathrm{mM}$ ascorbic acid and $0.25 \mathrm{mM} \mathrm{H}_{2} \mathrm{O}_{2}$. The reaction was started after the addition of $0.1 \mathrm{~mL}$ enzyme extract at $25^{\circ} \mathrm{C}$. The decrease in absorbance at $290 \mathrm{~nm}$ for one minute was recorded and the amount of ascorbate oxidized was calculated from the extinction coefficient $2.8 \mathrm{mM} \mathrm{cm}^{-1}$. The unit of activity is expressed as micromole of ascorbic acid oxidized $\min ^{-1}$ at $25^{\circ} \mathrm{C}$.

\section{Guaiacol Peroxidase (Enzyme number by NC IUBMB: EC 1.11.17)}

Guaiacol Peroxidase (GPX) activity was measured spectrophotometrically at $25^{\circ} \mathrm{C}$ by the method of TATIANA et al. (1999). The reaction mixture $(2.0 \mathrm{~mL})$ consisted of $0.05 \mathrm{M}$ po-

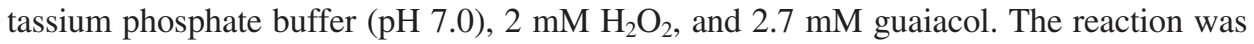
started by the addition of $0.1 \mathrm{~mL}$ enzyme extract. The initial rate of guaiacol oxidation was measured by the rate of formation of tetraguaiacol and was measured at $470 \mathrm{~nm}(\Delta \varepsilon=26.6$ $\mathrm{mM} \mathrm{cm}^{-1}$ ). One unit is defined as the amount of enzyme required to catalyze the conversion of one micromole of hydrogen peroxide, with guaiacol as hydrogen donor, per minute under specified conditions.

\section{Glutathione Reductase (Enzyme number by NC IUBMB: 1.6.4.2)}

Glutathione reductase (GR) activity was determined at $25^{\circ} \mathrm{C}$ by measuring the rate of NADPH oxidation as a decrease in absorbance at $340 \mathrm{~nm}\left(\varepsilon=6.2 \mathrm{mM} \mathrm{cm}^{-1}\right)$ according to the method of HALLIWELL and FOYER (1978). The reaction mixture (1.0 mL) consisted of $100 \mathrm{mM}$ Tris-HCl buffer (pH 7.8), $21 \mathrm{mM}$ EDTA, $0.005 \mathrm{mM}$ NADPH, $0.5 \mathrm{mM}$ oxidized glutathione, and the enzyme extract. NADPH was added to start the reaction. Unit activity is defined by the expression »one unit will reduce $1.0 \mu \mathrm{mol}$ of oxidized glutathione per minute under standard assay conditions $\ll$.

\section{Superoxide Dismutase (Enzyme number by NC IUBMB: EC 1.15.1.1)}

The assay for superoxide dismutase (SOD) activity was performed by following the method of BEYER and FRIDOVICH (1987). The assay mixture consisted of $27.0 \mathrm{~mL}$ of $0.05 \mathrm{M}$ potassium phosphate buffer ( $\mathrm{pH} 7.8), 1.5 \mathrm{~mL}$ of L-methionine (300 mg per $2.7 \mathrm{~mL}$ ), $1.0 \mathrm{~mL}$ of nitroblue tetrazolium salt $(14.4 \mathrm{mg}$ per $10 \mathrm{~mL})$, and $0.75 \mathrm{~mL}$ of Triton $\mathrm{X}-100$. Aliquots $(1.0 \mathrm{~mL})$ of this mixture were delivered into small glass tubes, followed by the addition of $20 \mu \mathrm{l}$ enzyme extract and $10 \mu \mathrm{L}$ of riboflavin ( $4.4 \mathrm{mg}$ per $100 \mathrm{~mL}$ ). The cocktail was mixed and then illuminated for 15 minutes in an aluminum foil-lined box, containing $25 \mathrm{~W}$ fluores- 
cent tubes. In a control tube the sample was replaced by $20 \mu \mathrm{L}$ of buffer and the absorbance was measured at $560 \mathrm{~nm}$. The reaction was stopped by switching off the light and placing the tubes in the dark. Increase in absorbance due to formation of formazan was measured at $560 \mathrm{~nm}$. Under the described conditions, the increase in absorbance in the control was taken as $100 \%$ and the enzyme activity in the samples were calculated by determining the percentage inhibition per minute. One unit of SOD is the amount of enzyme that causes a $50 \%$ inhibition of the rate for reduction of nitroblue tetrazolium salt under the conditions of the assay.

\section{Statistical analysis}

Data were subjected to FANOVA using Statistical Package for Social Sciences, VER 17.0. The four factors control, heavy metals, salt and combination of heavy metal and salt were computed. Results of the Bonferoni test are expressed by alphabet letters on bar graphs.

\section{Relative proportions of enzymes}

Proportions of antioxidant enzymes were calculated by the following formula:

Proportion of antioxidant enzymes $=\frac{\text { Specific activity of SOD in combined environment }}{\text { Specific activity of antioxidant enzyme }}$

\section{Results}

The effects of combined heavy metal (lead chloride and lead nitrate) and salt $(\mathrm{NaCl})$ stress on antioxidant enzyme activity in three week old Vigna radiata plants were examined. Applications of chloride and nitrate salt of lead significantly altered the superoxide dismutase (SOD) and catalase (CAT) activities in the saline $(\mathrm{NaCl})$ medium (Fig. 1). SOD activities were higher in a combined lead and salt stress environment than in an environment without $\mathrm{NaCl}$. Optimum activity was recorded in a plant when it was treated with a combination of $15 \mathrm{mg} \mathrm{L}^{-1}$ lead chloride and $75 \mathrm{mM} \mathrm{NaCl}$. However, $15 \mathrm{mg} \mathrm{L}^{-1}$ lead chloride without $\mathrm{NaCl}$ inhibited SOD activities. Likewise, SOD activities in $15 \mathrm{mg} \mathrm{L}^{-1}$ lead chloride and nitrate together with 150 and $225 \mathrm{mM} \mathrm{NaCl}$ solution were enhanced. It was observed that SOD had a greater activity in a two stress than in a single stress environment.

Single stresses, such as lead without $\mathrm{NaCl}$, showed enhancement in CAT activities, $\mathrm{s}$ optimum activity occurring in plants treated with $15 \mathrm{mg} \mathrm{L}^{-1}$ lead nitrate (Fig 1). However, at $30 \mathrm{mg} \mathrm{L}^{-1}$ lead nitrate with or without $\mathrm{NaCl}$ almost complete inhibition in the CAT activity was seen. With the application of heavy metals (lead chloride and lead nitrate) in a high saline environment $(150,225 \mathrm{mM} \mathrm{NaCl})$ fewer CAT than SOD activities were recorded. It was observed that CAT had less activity in a combined stress than in a single stress environment.

When lead chloride and nitrate were combined with a $\mathrm{NaCl}$ solution there was substantial improvement in ascorbate peroxidase (APX) activity compared to control (Fig 2). Maximum activities were measured when plants were treated with $15 \mathrm{mg} \mathrm{L}^{-1}$ lead nitrate together with all saline media $(75,150$ and $225 \mathrm{mM} \mathrm{NaCl})$. However, lead chloride and lead nitrate showed significant inhibition when provided without $\mathrm{NaCl}$. 


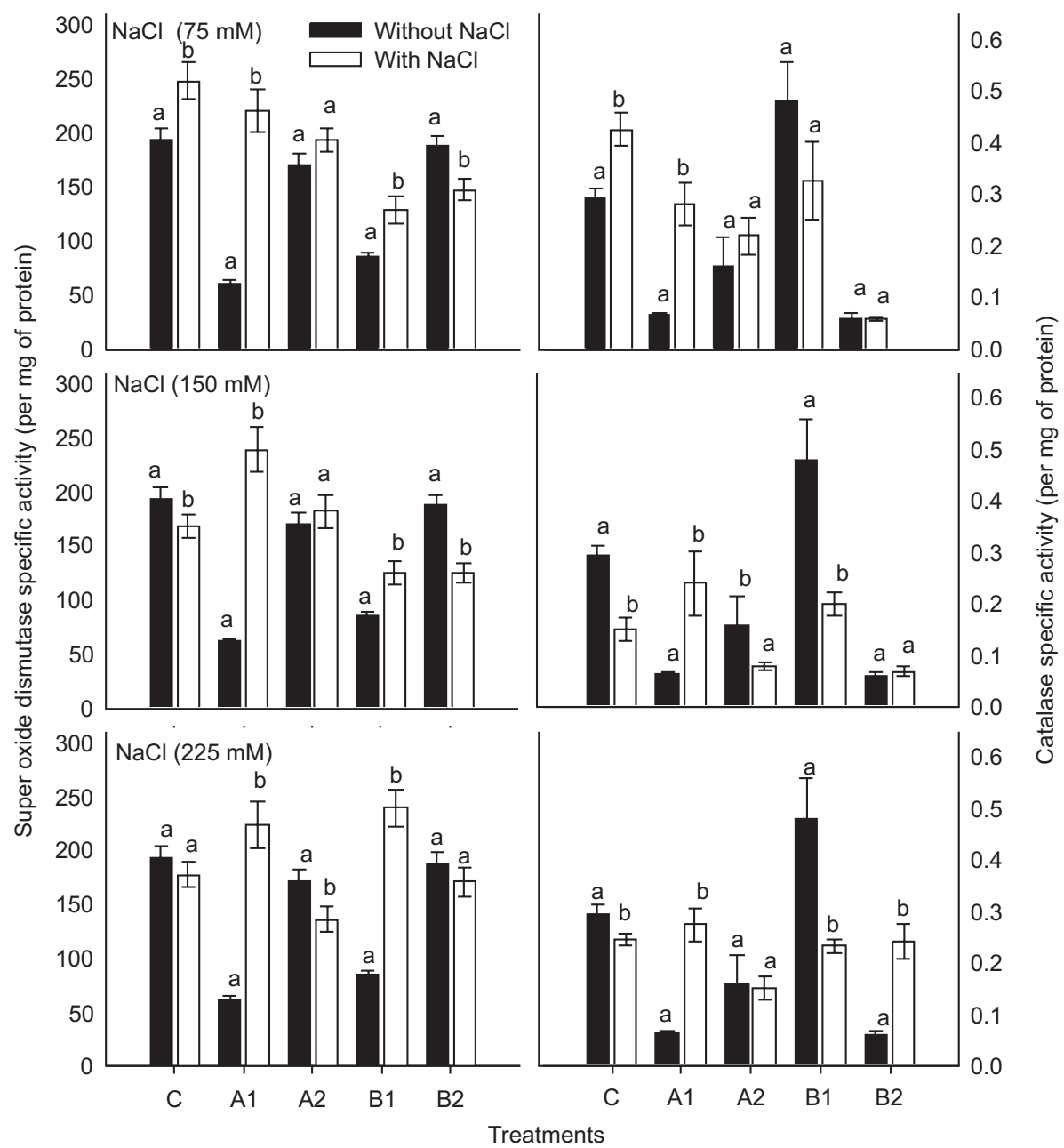

Fig. 1. Antioxidant enzyme's super oxide dismutase and catalase response in combined lead and saline environment. C - control, A- lead chloride, B - lead nitrate; B1 $=15, \mathrm{~B} 2=30 \mathrm{mg} \mathrm{L}^{-1}$ lead concentrations. Vertical lines on bar graphs represent mean \pm SE. Similar alphabet letters show non significant difference at $\mathrm{p}<0.05$ from corresponding ones measured on plant treated with lead salt with and without saline environment.

Glutathione reductase (GR) activities improved in a combined stress environment, with some exceptions, showing maximum activities in a plant treated with $15 \mathrm{mg} \mathrm{L}^{-1}$ lead chloride and $30 \mathrm{mg} \mathrm{L}^{-1}$ lead nitrate together with all saline concentrations (Fig 2). Application of single-stress lead chloride in particular caused considerable reduction in GR activities.

Guaiacol peroxidase (GPX) activities were enhanced by the combination of lead and salt stress compared to control (Fig. 3). However, optimum activities were recorded when plants were treated with $15 \mathrm{mg} \mathrm{L}^{-1}$ lead nitrate together with 75, 150 and $225 \mathrm{mM} \mathrm{NaCl}$. In general, a combination of heavy metal and salt stress improved GPX activities except when $30 \mathrm{mg}$ $\mathrm{L}^{-1}$ lead nitrate was applied together with 150 and $225 \mathrm{mM} \mathrm{NaCl}$. 


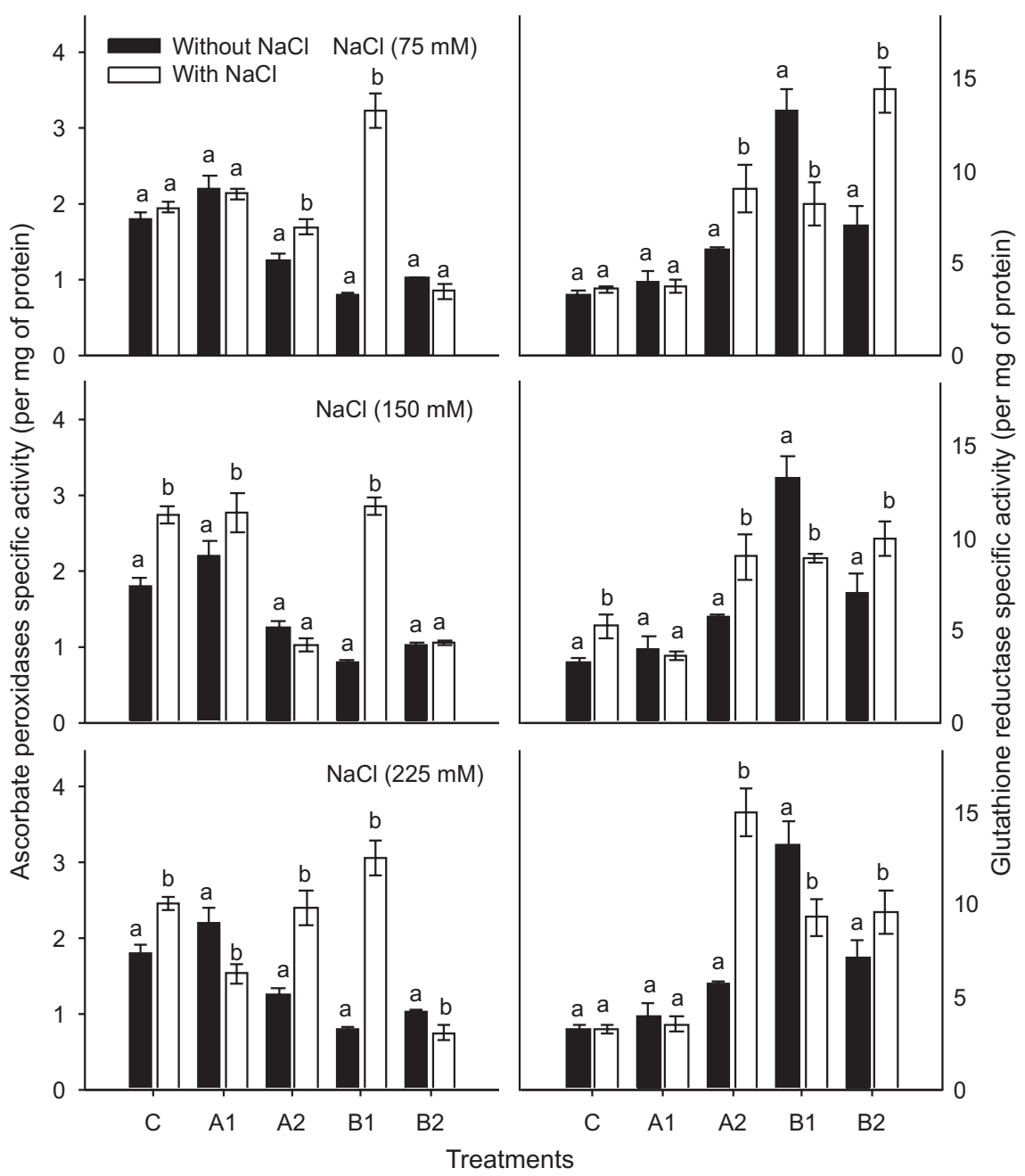

Fig. 2. Antioxidant enzyme's ascorbate peroxidase and glutathione rductase response in combined lead and saline environment. For symbol explanation see figure 1.

In order to compare the activity of antioxidant enzymes in combined stress environment, the relative enzyme activity performances in a combined stress environment were calculated. The study showed substantial activity of glutathione reductase (GR) after SOD (Fig 4). APX and GPX also had optimum activities compared to CAT. The highest SOD and GR enzyme units being found in a combined stress environment indicates a better tolerance against a combination of these stresses than found in other antioxidant enzymes.

\section{Discussion}

Antioxidant activities, in enzymes such as ascorbate peroxidase, catalase, superoxide dismutase activities are known to increase in a variety of environmental stresses like soil sa- 
linity, drought, extremes of temperature and heavy metals. Physiologically these stresses cause oxidative damage to plants either directly or indirectly (COMBA et al. 1998, BAISAK et al. 1994, BECANA et al. 2000, ShaH et al. 2001, Siddiqui et al. 2008). In fact, oxidative stress hazards are due to the production of reactive oxygen species which include superoxide radical $\left(\mathrm{O}_{2}^{+}\right)$, hydroxyl radical $\left(\mathrm{OH}^{+}\right)$and hydrogen peroxide $\left(\mathrm{H}_{2} \mathrm{O}_{2}\right)$. Reactive oxygen species (ROS) products in turn cause damage to the biomolecules by peroxidation, electrophilic substitution reaction, reduction of membrane lipids, proteins, chloroplast pigments, enzymes, nucleic acids, etc. (COMBA et al. 1998, BECANA et al. 2000, MAJEED et al. 2010).

In a defense system, SOD has a critical role in plants and functionally it dismutates superoxide radicals into water and $\mathrm{O}_{2}$. It has been reported that SOD activities increased in rice plants growing under toxic levels of $\mathrm{Pb}$ and salinity (VERMA and DUBEY 2003), water stress (ZHANG and KIRKHAM 1994), $\mathrm{Cd}, \mathrm{Pb}, \mathrm{Al}$ and $\mathrm{Cu}$ toxicity (CHONGPRADITNUM et al. 1992, VERMA and DUBEY 2003, MalecKa et al. 2007, MAJEed et al. 2010). Increase in SOD activity in response to stress seems to be used in de-novo synthesis of the further antioxidant enzymatic protein (FADZILLA et al. 1997, VERMA and DUBEY 2003). Therefore, it is presumed that SOD activities and synthesis of other antioxidant enzymatic protein like APX, CAT, GR, GPX in a combined stress environment are linked. It may also be suggested that a combination of two or more antioxidant enzymes activities is required to provide complete tolerance (complete detoxification of ROS) to plants under combined stress in particular.

Lower catalase activity in combined lead and salt stress environments is perhaps due to combined chloride toxicities, from both lead and sodium chloride. It is presumed that a combination of two chloride stresses may retard CAT protein and thus reduce the activity. It has been observed that catalase activity under lead chloride toxicity was delayed in the removal of $\mathrm{H}_{2} \mathrm{O}_{2}$ and peroxides, which results in lipid peroxidation and thus in growth retardation. Moreover, a similar decline in catalase activity was reported under salt stress (COMBA et al. 1998), chilling (Mishra and Singhal 1992), drought stress (LOZANO et al. 


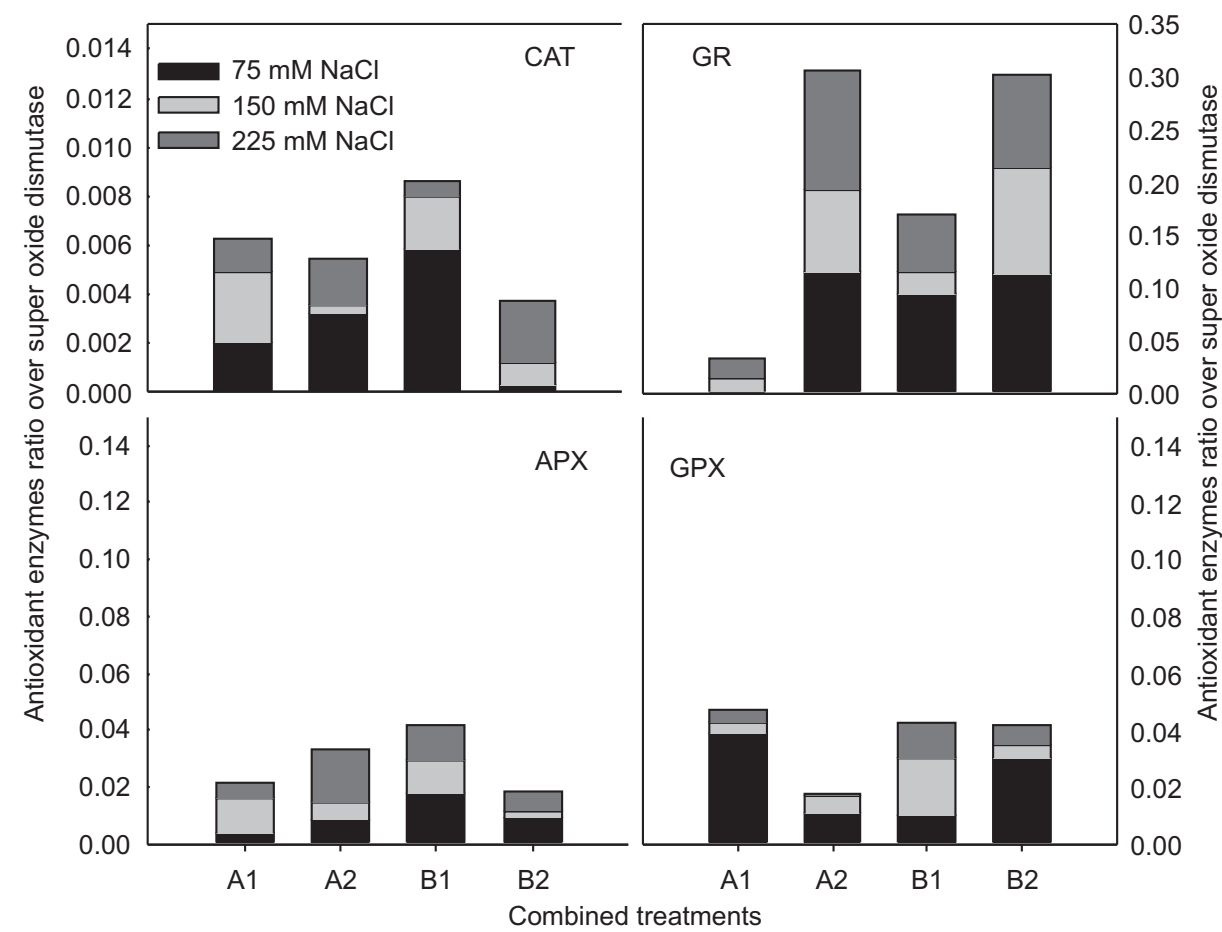

Fig. 4. Antioxidant enzymes proportion over super oxide dismutase (SOD) activity in combined lead and saline environments. APX - ascorbate peroxidase, CAT - catalase, GPX - guaiacol peroxidase, GR - glutathione reductase

1996) and hypoxia stress (USHIMARU 1992). Physiologically, reduction in catalase activity under stressful conditions has been attributed to the inactivation of enzyme protein due to ROS (USHIMARU 1992) decrease in enzyme synthesis or change in the assembly of enzyme subunits (VERMA and DUBEY 2003).

Ascorbate peroxidase (APX) guaiacol peroxidase (GPX) and glutathione reductase (GR) are crucial components after superoxide dismutase (SOD), which is required for complete neutralization of $\mathrm{H}_{2} \mathrm{O}_{2}$ (MACRAE and FERGUSON 1985, USHIMARU 1992). It is presumed that a system of antioxidant enzymes in a combined stress environment acts as a chain reaction. For instance, SOD first dismutated ROS into hydrogen peroxide which was then further converted into water and molecular oxygen by the activities of APX, GPX or GR in different proportions. It was presumed that SOD and CAT might act together to combat combined stress environment as it was observed in single stress study. However, in this study, CAT seems to be more sensitive under combined salt and lead stress. The better activity pattern of APX, GPX and GR in a combined stress environment showed a unique combination of activity patterns, not including CAT. Further, in a single stress study, APX exploits the reducing power of ascorbic acid more efficiently to get rid of potentially harmful $\mathrm{H}_{2} \mathrm{O}_{2}$ in response to abiotic stress (HERTwIG et al. 1992, JEBARA et al. 2005, SIDDIQUI et al. 2008, MAJEED et al. 2010). Likewise, glutathione reductase catalyzes the NADPH-dependent reduction of glutathione by its redox active thiol group, and glutathione is involved in the re- 
dox regulation of the cell cycle (KuBO et al. 1995, WECKX and CLIJSTERS 1996, HidEG et al. 1997, SIDDIQUI et al. 2008) and has often been considered to play a significant role in plant defense mechanisms against oxidative stress. Further the active role of GR activities has been reported by several workers in individual abiotic stress environments (KUBO et al. 1995, Weckx and Clijsters 1996, Hideg et al. 1997, Siddiqui et al. 2008, Majeed et al. 2010, AHMED et al. 2010). It is presumed that GR after the SOD in a combined stress environment may be involved in regulation in a cell cycle, which may not only provide tolerance but also improve plant growth in a combined stress environment.

Therefore, it is suggested that among the five antioxidant enzymes, SOD and GR are the two prominent enzymes in combined lead and $\mathrm{NaCl}$ stress environment and showed more substantial activity than APX, CAT and GPX. It may also be suggested that SOD and GR enzyme proteins are less sensitive to combined lead and $\mathrm{NaCl}$ salt and thus provide better tolerance in a combined stress environment.

\section{Acknowledgments}

Author acknowledge the Faculty of Science providing funds for this study and also Dr. Taek Ryoun Kwon and Dr. S-S Park, National Academy of Agriculture Sciences Stress Suwon South Korea for valuable suggestions.

\section{References}

Ahmed, R., Kima, Y. H., Kim, M. D., Kwon, S-Y., Cho, K., Lee, H-S., KwaK, S-S., 2010: Simultaneous expression of choline oxidase, superoxide dismutase and ascorbate peroxidase in potato plant chloroplasts provides synergistically enhanced protection against various abiotic stresses. Physiologia Plantarum 138, 520-533.

Allen, R. D., Webb, R. P., Schake, S. A., 1997: Use of transgenic plants to study antioxidant defenses. Free Radical Biology and Medicine 23, 473-479.

BAISAK, R., RANA, D. A., ACHARYA, P. B. B., KAR, M., 1994: Alterations in the activities of active oxygen scavenging enzymes of wheat leaves subjected to water stress. Plant Cell Physiology 35, 489-495.

Becana, M., Dalton, D. A., Moran, J. F., Iturbe-Ormaetxe, I., Matamoros, M. A., Rubio, M. C., 2000: Reactive oxygen species and antioxidants in legume nodules. Physiologia Plantarum 109, 372-81.

BEYER, W. F., FrIDOVICH, I., 1987: Assaying for superoxide dismutase activity:some large consequences of minor changes in condition. Annals of Biochemistry 161, 559-566.

BRADFORD, M. M., 1976: A rapid and sensitive method for the quantitation of microgram quantities of protein utilizing the principle of protein-dye binding. Annals of Biochemistry $72,248-254$.

Chongpraditnum, P., Mori, S., Chino, M., 1992: Excess copper induces a cytosolic Cu, Zn-superoxide dismutase in soybean root. Plant Cell Physiology 33, 239-244.

Comba, M. E., Benavides, M. P., Tomaro, M. L., 1998: Effect of salt stress on antioxidant defence system in soybean root nodules. Australian Journal of Plant Physiology 25, $665-671$. 
DudLey, L. M., SHANI, U., 2003: Modeling plant response to drought and salt stress: Reformulation of the root-sink term. Vadose Zone Journal 2, 751-758.

FADZILla, N. M., Finch, R. P., Burdon, R. H., 1997: Salinity oxidative stress and antioxidant responses. Journal of Experimental Botany 48, 325-31.

Halliwell, B., Foyer, C. H., 1978: Properties and physiological function of a glutathione reductase purified from spinach leaves by affinity chromatography. Planta 139, 9-17,

Hameed, N., Siddiqui, Z. S., Ahmed, S., 2000: Effect of copper and lead on germination, accumulation and phenolic contents of Spinancea oleracea and Lycopersicum esculentum. Pakistan Journal of Biological Sciences 4, 809-811.

Hertwig, B., Streb, P., Feieraband, J., 1992: Light dependence of catalase synthesis and degradation in leaves and the influence of interfering stress conditions. Plant Physiology $100,1547-1553$.

Hideg, E., Mano, J., OHno, C., AsAda, K., 1997: Increased levels of monodehydroascorbate radical in UV-B-irradiated broad bean leaves. Plant Cell Physiology 38, 684-690.

HoAgland, D. R., ARnON, D. I., 1950: The water-culture method for growing plants without soil. Circular 347, University of Californias, Agricultural Experimental Station, Berkley, 1-32.

Jakab, G., Ton, J., Flors, V., Zimmerli, L., MetrauX, J. P., Mauch-Mani, B., 2005: Enhancing Arabidopsis salt and drought stress tolerance by chemical priming for its abscisic acid responses. Plant Physiology 139, 267-274.

Jebara, S., Jebara, M., Limam, F., AouAni, M. E., 2005: Changes in ascorbate peroxidase, catalase, guaiacol peroxidase and superoxide dismutase activities in common bean (Phaseolus vulgaris) nodules under salt stress. Journal of Plant Physiology 162, 929936.

Jetley, U. K., Choudhary, M., Fatma, T., 2004: Evaluation of biochemical productivity cyonobacterium Spirulina platensis-S5 under heavy metal stress. Asian Journal of Chemistry 16, 1524-1528.

Kubo, A., SaJi, H., TAnaKa, K., Kundo, N., 1995: Expression of Arabidopsis cytosolic ascorbate peroxidase gene in response to ozone or sulphur dioxide. Plant Molecular Biology 29, 479-489.

KumAR, V., KumAR, D., 1996: Response of Indian mustard to saline water application at different growth stages. Trans Indian Society Desert Technology 15, 121-125.

Kwon, S. Y., JeOng, Y. J., LeE, H. S., KIM, J. S., Cho, K. Y., Allen, R. D., KwAK, S. S., 2002: Enhanced tolerances of transgenic tobacco plants expressing both superoxide dismutase and ascorbate peroxidase in chloroplasts against methyl viologen-mediated oxidative stress. Plant Cell Environment 25, 873-882.

Lozano, R., Azcon, R., Palma, J. M., 1996: SOD and drought stress in Lactua sativa. New Phytologist 136, 329-331.

Macrae, E. A., Ferguson, I. B., 1985: Changes in catalase activity and hydrogen peroxide concentration in plants in response to low temperature. Physiologia Plantrum 65, 51-56.

Majeed, A., NisAR, M. F., Hussain, K., 2010: Effect of saline culture on the concentration of $\mathrm{Na}^{+}, \mathrm{K}^{+}$and $\mathrm{Cl}^{-}$in Agrostis tolonifera. Current Research Journal of Biological Sciences $2,76-82$. 
Malecka, A., Jarmuszkiewicz, W., Tomaszewska, B., 2001: Antioxidative defense to lead stress in subcellular compartments of pea root cells. Acta Biochemica Polonica 48, 687-698.

Mishra, R. K., Singhal, G. S., 1992: Function of photosynthetic apparatus of intact wheat leaves under high light and heat stress and its relationship with peroxidation of thylakoid lipids. Plant Physiology 98, 1-6.

NAKANO, Y., AsAdA, K., 1981: Hydrogen peroxide is scavenged by ascorbate specific peroxidase in spinach chloroplasts. Plant Cell Physiology 22, 867-880.

Nawaz, K., Hussain, K., Majeed, A., Faraha, K., Shahida, A., Kazim, A., 2010: Fatality of salt stress to plants: Morphological, physiological and biochemical aspects. African Journal of Biotechnology 9, 5475-5480.

Patterson, B. D., Macrae, E. A., Ferguson, I. B., 1984: Estimation of hydrogen peroxide in plant extracts using titanium (IV). Annals of Biochemistry 139, 487-492.

Shah, K., Kumar, R. G., Verma, S., Dubey, R. S., 2001: Effect of cadmium on lipid peroxidation, superoxide anion generation and activities of antioxidant enzymes in growing rice seedlings. Plant Science 161, 1135-1144.

Sharma, P. C., GiLl, K. C., 1994: Salinity-induced effect on biomass, yield, yield attributing characters and ionic contents in genotypes of Indian mustard. Indian Journal of Agricultural Sciences 64, 785-788.

ShINOZAKI, K., YAMAGUCHI-ShINOZAKI, K., 2000: Molecular responses to dehydration and low temperature: differences and cross-talk between two stress signaling pathways. Current Opinion in Plant Biology 3, 217-223.

SidDiqui, Z. S., Khan, M. A., 2011: The role enzyme amylase in two germinating seed morphs of Halophyrum mucronatum (L.) Stapf in saline and non-saline environment. Acta Physiologeae Plantrum 33, 1185-1197.

Siddiqui, Z. S., Khan, M. A., Beomgi, K., Huang, J-S., Kwon, T. R., 2008: Physiological response of Brassica napus genotypes in combined stress. Plant Stress 2, 78-83.

SINHA, T. S., 1991: Genetic adaptation of Indian mustard to semiarid saline-soil condition. Indian Journal of Agricultural Science 61, 251-254.

Tatiana, Z., Yamashita, K., Matsumoto, H., 1999: Iron deficiency Induced changes in ascorbate content and enzyme activities related to ascorbate metabolism in cucumber root. Plant Cell Physiology 40, 273-280.

Ushimaru, T., ShibasaKa, M., Tsuj, H., 1992: Development of $\mathrm{O}_{2}{ }^{+}$detoxification system during adaptation to air of submerged rice seedlings. Plant Cell Physiology 33, 10651071.

Verma, S., DubEY, R. S., 2003: Lead toxicity induces lipid peroxidation and alters the activities of antioxidant enzymes in growing rice plants. Plant Science 164, 645-655.

Wang, W., Vinocur, B., Altman, A., 2003: Plant responses to drought, salinity and extreme temperatures: towards genetic engineering for stress tolerance. Planta 18, 1-14.

WANG, Z., HuAng, B., 2004: Physiological recovery of Kentucky bluegrass from simultaneous drought and heat stress. Crop Science 44, 1729-1736. 
WeCkX, J. E. J., CliJsters, H. M. M., 1996: Oxidative damage and defense mechanisms in primary leaves of Phaseolus vulgaris as a result of root assimilation of toxic mounts of copper. Physiologia Plantrum 96, 506-512.

ZhanG, J., Kirkham, M. B.,1994: Drought-stress induced changes in activities of superoxide dismutase, catalase and peroxidase in wheat species. Plant Cell Physiology 35, $785-791$. 